\title{
The Effectiveness of Whispering Game to Students' Vocabulary Mastery
}

\author{
Sari Delima Sihaloho ${ }^{1}$, Juwita Boneka Sinaga ${ }^{2}$, Sulastri Manurung ${ }^{3}$ \\ English Education Department \\ University of Riau Kepulauan \\ saridelima21@gmail.com¹, juwitaboneka@gmail.com², lastri.manru@yahoo.com ${ }^{3}$
}

\begin{abstract}
In this research, there are many problems in learning process in the class. The problems are lack of vocabulary, and method of teaching vocabulary used. This research has purpose to students' vocabulary mastery by using whispering game at the SMP Kartini II Batam academic Year 2015/2016. This research is quantitative research. The researcher used total sampling. The experimental class was taught using whispering game, whereas the control class was taught using lecturing method. In this research, the researcher gave 20 of questions in multiple choices form. The result of analysis can be concluded that there was significant effect. It was showed $t_{\text {count }}>t_{\text {table }}(3,01>2,01)$ so $H_{0}$ was rejected and $H_{a}$ was accepted. The result of analysis can be concluded that the use of whispering game at SMP Kartini II Batam in academic Year 2015/2016 gave significant effect in the students' activity in learning process than the use of close procedure.
\end{abstract}

Keyword : whispering game, vocabulary mastery

\section{INTRODUCTION}

Language has important rule for human life especially for communication. English is one of International language. We use English, especially for communication to other people who comes from different countries in the world. English is used many aspects such as business, technology, science, and education. In Indonesia the government inserted English in the school curriculum component from elementary school until university level. Teaching English as foreign language is not easy because English is a foreign language. Therefore the teachers have responsibility to teach student to understand the lesson.

In learning process, students often got the difficulties in understanding the lesson. The problems are because the students are lack of vocabulary and lack of motivation in learning English. Therefore teacher should use an appropriate method and technique in teaching process. So the student can understand and enjoy in learning process. In order to 
master English, students need to know and on the statement, it understand vocabularies in different context.

The next problem is concerned with the technique of teaching vocabulary and media used. The teaching of vocabulary needs more attention because vocabulary mastery is important in language proficiency. Teacher should prepare all the component in teaching learning process well. The component are the media, the material, and teaching method. Games are usually used for teaching language for young learners, because it is fun and motivating.

Learning by games is suitable for young learner, give the student opportunity to learn her language experience through fun and play. Whispering game is one method that can be applied in teaching English to improve vocabulary.

The researcher focused on the whispering game. The researcher limited the problem of the study about the effectiveness of whispering game to students' vocabulary mastery at the eight grade at SMP Kartini II Batam. Based on the limitation above, the problem of the research could be formulated: "Was there any significant effect of whispering game to students' vocabulary mastery at the eight grade at SMP Kartini II Batam in the academic year of 2015/2016.”

Based on the formulation above, the research had the objective of the study is to identify whether whispering game is effective to students' vocabulary mastery or not at the eight grade of SMP Kartini II Batam in academic year 2015/2016.

Vocabulary can be defined as a number of vocabulary (words) in a language which contains information about its meaning, form, and usage in context of communication. It is the basic knowledge that students should master first before mastering English. From the definitions above, it can be concluded that vocabulary is the knowledge of words and word meanings.

\section{METHODOLOGY}

The kind of this research was an experimental research It was the type of research which focused on establish the cause-effect relationships. According to Sugiyono (2013:72), experimental research is a research method that used to find influencing a treatment to the other in controlled condition. In this research, the researcher analyzed the effectiveness of whispering game to students’ vocabulary mastery. 
The experimental design must have two groups: an experimental group and control group.

\section{Hypothesis Testing}

According to Arikunto (2006:311), t-test of two independent variables are done to compare both variables whether they are similar or different. The T-test formula was taken from Arikunto (2006:311). The formula can be seen as below :

$$
\mathrm{t}_{\text {test }}=\frac{M_{x}-M_{y}}{\sqrt{\left\{\frac{\sum x^{2}+\sum y^{2}}{N_{x}+N_{Y}-2}\right\}\left\{\frac{1}{N_{X}}+\frac{1}{N_{Y}}\right\}}}
$$

Where:

$\mathrm{M}=$ The mean of each group

$\mathrm{N}=$ Total of sample

$\mathrm{x}=$ Deviation for each value $\mathrm{X}_{2}$ and $\mathrm{X}_{1}$

$\mathrm{Y}=$ Deviation of each value $\mathrm{Y}_{2}$ and $\mathrm{Y}_{1}$

\section{Statistical Hypothesis}

The writer formulated the statistical hypothesis as follow :

Ho : Is accepted if $t_{\text {test }}<t$ table. It means that Whispering Game does not give significant effect to students' vocabulary mastery at the eight grade of SMP Kartini II Batam in academic year 2015/2016.

Ha : Is accepted if $t_{\text {test }}>t_{\text {table. }}$ It means that Whispering Game gives significant effect to students' vocabulary mastery at the eight grade of SMP Kartini II Batam in academic year 2015/2016. 


\section{RESULTS}

\section{Testing Instrument}

\section{Normality Test}

The statistic formula of Normality test used chi square's formula.

The summary of Normality test could be seen at table below:

Table 1. Summary of normality testing

\begin{tabular}{|c|c|c|c|c|}
\hline No. & Variable & $\mathrm{X}_{\text {count }}^{2}$ & $\mathrm{X}_{\text {table }}^{2}$ & Note \\
\hline 1 & $\begin{array}{l}\text { Vocabulary Mastery } \\
\text { of Experimental Class } \\
\text { in Pre Test }\end{array}$ & 8.29 & 11.070 & $\begin{array}{c}\mathbf{X}_{\text {count }}<\mathbf{X}^{2} \text { table } \\
\text { Normal Distributed }\end{array}$ \\
\hline 2 & $\begin{array}{l}\text { Vocabulary Mastery } \\
\text { of Experimental Class } \\
\text { in Post Test }\end{array}$ & 9.96 & 11.070 & $\begin{array}{c}\mathbf{X}_{\text {count }}^{2}<\mathbf{X}^{2} \text { table } \\
\text { Normal Distributed }\end{array}$ \\
\hline 3 & $\begin{array}{l}\text { Vocabulary Mastery } \\
\text { of Control Class in } \\
\text { Pre Test }\end{array}$ & 4.92 & 11.070 & $\begin{array}{c}\mathbf{X}_{\text {count }}<\mathbf{X}^{2} \text { table } \\
\text { Normal Distributed }\end{array}$ \\
\hline 4 & $\begin{array}{l}\text { Vocabulary Mastery } \\
\text { of Control Class in } \\
\text { Post Test }\end{array}$ & 4.92 & 11.070 & $\begin{array}{c}\mathbf{X}_{\text {count }}^{2}<\mathbf{X}^{2} \text { table } \\
\text { Normal Distributed }\end{array}$ \\
\hline
\end{tabular}

It could be drawn as a conclusion that the data were normally distributed. Because all of the results of $\mathrm{X}^{2}$ count was lower than $\mathrm{X}^{2}$ table.

\section{Homogeneity Test}

The formula of homogeneity test used formula by Riduwan (2011:186) as follow:

$$
\mathrm{F}=\frac{\text { The biggest variance }}{\text { The lower variance }}
$$

The summary of Homogeneity test could be seen at table below: 
Table 2. Summary of homogeneity testing

\begin{tabular}{clccl}
\hline No & \multicolumn{1}{c}{ Variable } & F count & $\mathbf{F}_{\text {table }}$ & Conclusion \\
\hline 1 & $\begin{array}{l}\text { Vocabulary Mastery in } \\
\text { Pre Test }\end{array}$ & 1.080 & 1.984 & Homogeneous \\
\hline 2 & $\begin{array}{l}\text { Vocabulary Mastery in } \\
\text { Post Test }\end{array}$ & 1.392 & 1.984 & Homogeneous \\
\hline
\end{tabular}

The table above showed that the values of $\mathrm{f}_{\text {count }}$ was lower than the value of $\mathrm{f}_{\text {table }},\left(\mathrm{f}_{\text {count }}<\mathrm{f}_{\text {table }}\right)$. It indicated that the datas from pre test and post test were homogeneous.

Based on the statistical analysis of hypothesis testing above, the writer discussed the treatment of Whispering Game in students' vocabulary mastery. It was found that the students who were taught by whispering game have been improved in parts students' vocabulary mastery than the students who were taught by using lecturing method because the students who were taught by whispering game can easily increase new vocabulary. Students could be easier and enjoy to understand in learning process.

Based on the data analysis about students' vocabulary mastery, the writer found out that the mean of students in experimental class was higher than the mean of students in control class, then the tcount was higher than ttable (3.01> 2.01), which means the Null Hypothesis is accepted, so that whispering game was give significant effect to students' vocabulary mastery at the eight grade of SMP Kartini II Batam.

\section{DISCUSSION}

Based on the research conducted for eight grade students of junior high school at SMP Kartini II Batam. The sum score of experimental group for pre-test was 1.290, while the score post-test was 1.740 . It showed that in experimental group there was significant different between pre-test and post-test score $(1.740-1.290)$ was 450 . Which the post-test was higher than pre-test score. The sum score of control group for pre-test was 1.320 , while the score post-test was 1.565. In the control group that showed there was significant different between pre-test and post-test score (1.565-1.320) was 245 which the post-test was higher than pretest score. 
Based on the explanation, it was shown the students that who got treatment by using whispering game obtained more significant improvement than the students who got treatment with close procedure.

The result of the research of test also proved that whispering game gave significant effect to students vocabulary mastery. It was shown from the calculation between pre-test and post-test score. In the pre-test, calculation both of group experimental and control group the value t obtained was 3.01 while the value of t table was 2.01 with the level of significant 0.05. It showed that the value of table (2.01), was smaller than the value of $t$ obtained was (3.01). it means that the alternative hypothesis was accepted.

There were two implication for students and teacher, they are:

(1) Students can increase vocabulary mastery so they will master in four English language skills that are speaking, reading, writing, and listening. Students will be easier and enjoy to understand in learning process.

(2) Whispering game is easy for use in teaching vocabulary mastery. This method can help the teacher in learning English teacher so that students will be easier to know and understand the lesson and students feel interesting in learning English.

Dealing with the practical development, the use of Whispering Game can be applied in teaching vocabulary in students house to students' vocabulary mastery guide the parents. To have a certain competences the teacher should be able to select the right and appropriate topic for students in term of learning objectives and students needs and interest. Moreover, the teacher also should have capability in designing and presenting the material for the students. As a result, the students will be more interest and easier in comprehending the material.

Dealing with the research finding, the following suggestion as the outcomes of the study is put forward. Those are expected to be useful for come writer, the teacher English, and for whom that may be concerned with English education and particularly teaching vocabulary. 


\section{REFERENCES}

Arikunto. (2006). Dasar-dasar evaluasi pendidikan. Jakarta: Bumi Aksara.

Azar A.(2012). The effect of games on EFL learners' vocabulary learning strategies. Maragheh Branch-Islamic Azad University. Iran.

Sugiyono. (2013). Metode penelitian kuantitatif, kualitatif, dan R\&D. Jakarta: Alfabeta.

Riduwan. (2012). Pengantar statistika. Bandung: Alfabeta Bandung. 